\title{
Article \\ Fuzzy-Based Investigation of Challenges for the Deployment of Renewable Energy Power Generation
}

\author{
Shabbiruddin ${ }^{1}\left(\mathbb{D}\right.$, Neeraj Kanwar ${ }^{2, *(\mathbb{D})}$, Vinay Kumar Jadoun ${ }^{3}{ }^{(}$, Majed A. Alotaibi ${ }^{4, *}{ }^{\mathbb{C}}$, Hasmat Malik ${ }^{5, *(\mathbb{C})}$ \\ and Mohammed E. Nassar ${ }^{6}$ \\ 1 Department of Electrical and Electronics Engineering, Sikkim Manipal Institute of Technology, \\ Sikkim Manipal University, Gangtok 737136, India; shabbiruddin85@yahoo.com \\ 2 Department of Electrical Engineering, Manipal University Jaipur, Jaipur 303007, India \\ 3 Department of Electrical \& Electronics Engineering, Manipal Institute of Technology, \\ Manipal Academy of Higher Education, Manipal 576104, India; vjadounmnit@gmail.com \\ 4 Department of Electrical Engineering, College of Engineering, King Saud University, \\ Riyadh 11421, Saudi Arabia \\ 5 BEARS, NUS Campus, University Town, Singapore 138602, Singapore \\ 6 Department of Electrical and Computer Engineering, University of Waterloo, Waterloo, ON N2L 3G1, Canada; \\ mnassar@uwateroo.ca \\ * Correspondence: nk12.mnit@gmail.com (N.K.); majedalotaibi@ksu.edu.sa (M.A.A.); \\ hasmat.malik@gmail.com (H.M.)
}

check for updates

Citation: Shabbiruddin; Kanwar, N.; Jadoun, V.K.; Alotaibi, M.A.; Malik, H.; E. Nassar, M. Fuzzy-Based Investigation of Challenges for the Deployment of Renewable Energy Power Generation. Energies 2022, 15, 58. https://doi.org/10.3390/ en15010058

Academic Editors: Galih Bangga and Len Gelman

Received: 11 November 2021

Accepted: 14 December 2021

Published: 22 December 2021

Publisher's Note: MDPI stays neutral with regard to jurisdictional claims in published maps and institutional affiliations.

Copyright: (C) 2021 by the authors. Licensee MDPI, Basel, Switzerland. This article is an open access article distributed under the terms and conditions of the Creative Commons Attribution (CC BY) license (https:/ / creativecommons.org/licenses/by/ $4.0 /)$.

\begin{abstract}
Studying and analyzing the challenges that the renewable energy sector faces can help evaluate the risks and improve the planning. This research is done by considering the challenges in the implementation of sustainable generation of electricity through RESs in India, based on factors, including technical, financial, involvement, support, and others. The triangular fuzzy number (TFN) method, based on fuzzy logic concept, is used to analyze the challenges in this study. In general, TFN comprises of three numbers, likewise Gaussian fuzzy numbers, trapezoidal fuzzy numbers also exist. The classified sets of numbers are denotations to decision-makers' perspective or a choice towards the criterion preference. Although alternatives are many to design a fuzzy set depending on elements count, the TFNs are the ones considered as actual representations of a fuzzy number. On the other hand, cases the Gaussian or trapezoidal, are manifestations of fuzzy intervals. Another argument is that the membership function shape corresponding to the number of fuzzy set elements is largely dependent on the study. The challenges identified along with analysis in this paper will help the industry, governments, and policymakers focus and tackle essential issues to facilitate further the deployment of RESs in India towards a more sustainable country.
\end{abstract}

Keywords: distributed generation; fuzzy logic; TFN; renewable energy power generation

\section{Introduction}

The rapid depletion of fossil fuels and their fluctuating prices along with global warming concerns have prompted the demand from government, consumers and the public at large, on both the governments and on the private firms to adopt more sustainable projects for power generation and to reduce the harmful emissions. India is a newly industrialized country which making a tangible step towards a transition to sustainable energy. As part of the global trend towards sustainability, India has accepted the challenge and committed to reduce the pollution by $33 \%$ to $35 \%$ by 2030 [1]. It is estimated that sustainable energy contribution in overall electricity generation rose from $23.7 \%$ in 2015 to $24.5 \%$ in 2016 . The shares of major renewable sources were $16.6 \%$ for hydro, $4 \%$ for wind, $2 \%$ for biomass energy, $1.5 \%$ for solar and $0.4 \%$ for geothermal and others [2]. However, $75.5 \%$ of electricity is still being generated from non-renewable sources. The reasons for this include economic factor especially for coal which is cheaper than any renewable resource and still abundant in India. To plan and implement future sustainable power generation, 
it is necessary to identify the most important challenges and having the proper balance between economic growth, electricity generation, the impacts on the environment, as well as other considerations [3].

Despite the ingeniousness in its achievements in the sector, being a developing country, the government of India still has high goals and targets set for its renewable energy plans. The country which has a total installed power capacity of 369 GW aims to stretch its installed renewable energy consumption to $175 \mathrm{GW}$ by 2022 , about $50 \%$ of its current total capacity. This target is expected to multiply to $450 \mathrm{GW}$ by 2030 [4]. Huge investments by foreign investors, scaling up to 5.26 billion dollars as of the April-December 2019 tenure, have further provided the country with the flexibility of modern options to work with to achieve its target [5].

In the field of renewable energy, the most affected sectors are of solar and wind energy. Almost $80 \%$ of solar cells and modules were being imported from China, which is almost at a complete stall at present. The reason for the delay is production losses and quality checkoriented issues, as informed by Chinese companies to the Indian government handling the same [6]. With India being the fourth-largest onshore wind market by installation with 38.06 GW of wind capacity as of 2019, the wind installation in India is also expected to be affected by the outbreak. Challenges such as land acquisition, grid unavailability, supply chain bottlenecks, and lack of project financing due to the COVID-19 outbreak is making it difficult to achieve any previously set targets by the government. There being a shortfall of alternatives in raw materials and insufficient capability to meet deadlines along with delays in transition, the wind energy sector of the country will have its share of adversities as well, drastically affecting installations of new wind projects in the current year [7]

Many studies, including recent ones, have been dedicated to sustainable electricity generation [8]. The two major challenges are securing the energy supply and limiting the negative effects on the environment $[9,10]$. It is of great concern and a challenge for the Indian government that 1.4 billion people still lack access to electricity. Part of the challenge in providing access to electricity is related to the fact that $85 \%$ of India's population still lives in rural areas. It is expected that by 2030, the number of rural communities that rely on traditional use of biomass (direct combustion of biomass for cooking, drying, and charcoal production) would rise from 2.7 to 2.8 billion [11].

The dominance of fossil fuels-oil, gas and coal, in power generation, the population growth over the past decades, and the increase in demand for energy are resulting in global challenges associated with the rise in carbon dioxide $\left(\mathrm{CO}_{2}\right)$ emissions [12]. Controlling the greenhouse gas emissions, which are associated with climate change, can be achieved by transforming the present energy systems, which are mostly based on fossil fuels, to use renewable energy (RE) sources [13].

Addressing major issues such as RE requires global monitoring and modelling of factors such as economic, environmental and social $[14,15]$. In low-carbon energy economies, which is based on low carbon power sources, RE sources could be the major energy supply option. In order to tap the widely available RE sources, the existing energy systems need to be altered. One of the major challenges for the twenty-first century is making the transition from the traditional to RE [16]. Deploying the power generation using RE, has a number of challenges are yet to be addressed, which are of major concern.

The government of India is interested in utilizing non-conventional resources and deploying them as significant sources for electricity generation. Both the government and the private sector entities are aware of the potential of different scenarios for the use of RE that could lead the country in establishing a sustainable energy system. While different sources of RE are available, investment decisions should be informed by the potential for success, which includes the appropriateness of each location. To allocate the investments appropriately in different RE resources, it requires an extensive study of the country's power system, about multiple challenges.

Many studies in the literature use multi-criteria analysis in the area of RE, including selecting locations and identifying the most promising RE sources. The multi-criteria 
decision-making (MCDM) tools have been largely applied in research. This includes various MCDM tools applied in the planning of processes based on energy $[17,18]$, water resource management [19], material selection techniques [20,21], and machine applications [22] with the ranking of different renewable power systems [23]. GIS-based selection for solar power site suitability [24], use of AHP for micro-grid source selection [25], implementation of solar plant through MCDM [26], integrated approach using GIS-MCDM for optimal selection of hydropower location [27], fuzzy-MULTIMOORA approach for energy storage technologies [28], use of MCDM in renewable energy project [29,30] are some of the relevant literatures. The growth of RE share in total energy production is slow, but RE is certainly becoming a significant alternative worldwide. In this study, various challenges that exist for different RE sub-sectors have been identified and classified in the following categories: technical, involvement and support, financial and others. The goal is to identify and rank all the challenges to ultimately help the government, energy planners and power industry making investments in the area of RE to handle these challenges.

The work proposed in this research is a step on the path towards a more sustainable environment. The results could encourage the investors and policymakers to consider the challenges identified and to plan how to deal with them before making investments. With appropriate and timely government incentives and proper planning and implementation, India could soon emerge as a sustainable nation in terms of power production. Power generated from RE sources at fixed locations (bulk power) and at various places (small scale power) can be fed into the national grid across India. This would reduce the country's dependence on conventional energy sources. India has been implementing a singly connected grid for the whole nation, and this would facilitate integrating the power generated from distributed generation RE sources into the grid. The paper is structured as follows: First, a literature review (Section 1) highlighting the gaps in prior research and the novelty (Section 2) of this research is presented. The approach of the study is then explained (Section 3). The categorized list of challenges, along with the explanation of each challenge follows (Section 3.1). The process to obtain the ranking of the challenges, including the application of the TFN method calculations is presented next (Sections 3.2 and 4). Results (Section 5) obtained are analyzed followed by conclusion (Section 6) and the directions for future research are suggested.

\section{Novelty}

There have been many studies using soft computing (SC) techniques in the area of RE. The techniques tackle the decision problems ranging from location selection to selection of most promising RE sources for an area. Work are available in the literature, where implementation of solar plant through MCDM [30,31], integrated approach using GIS for establishing floating solar plants [32], Q-GIS-based study on RE generation in hilly terrain [33], mapping of hybrid RE system using MCDM [34] and other purposeful selection related to RE $[35,36]$. However, as per the knowledge of authors, the challenges to RE implementation have not been formally analyzed by the research community.

This research is novel on several levels. First, the research problem is identifying and analyzing the challenges in RE implementation that were not previously studied, to the authors' best knowledge. Additionally, there is novelty in the use of associated methods; since the inputs to the evaluation problem have some inherent ambiguity the weights of the challenges provided by decision/policymakers in order to account for uncertainty. The TFN-based fuzzy approach is appropriate in such case, as it reduces large deviations in the results. There is a research gap when it comes to the disconnect between establishing RE systems and their usage. As a result, even desiring states fail to utilize the systems within their network fully. Thus, using this novel approach identification and analysis of the challenges faced by renewable energy sector on technical, financial, and other grounds are classified and ranked This work will be of great help to planners and investors to give a pace to the renewable energy sector development. This study takes a step towards overcoming this gap and promotes further research on similar topics. 


\section{Methodology}

The process of research presented in this paper is illustrated in Figure 1. The flow chart in Figure 1 outlines the process of identifying key RE challenges in India. The use of MCDM for decision problems is common in research and in some practical cases such as in power system, energy-based applications like biomass facility location using MCDM [37], Q-GIS MCDM-based approach for potential site selection [38,39], an overview of AHP [40], MCDM-based application towards RE [41,42]. Here, in this approach, the TFNbased fuzzy model is used for ranking. Thirteen challenges that governments and private firms face in the RE domain, which are slowing down the transition from conventional to non-conventional energy sources, have been identified.

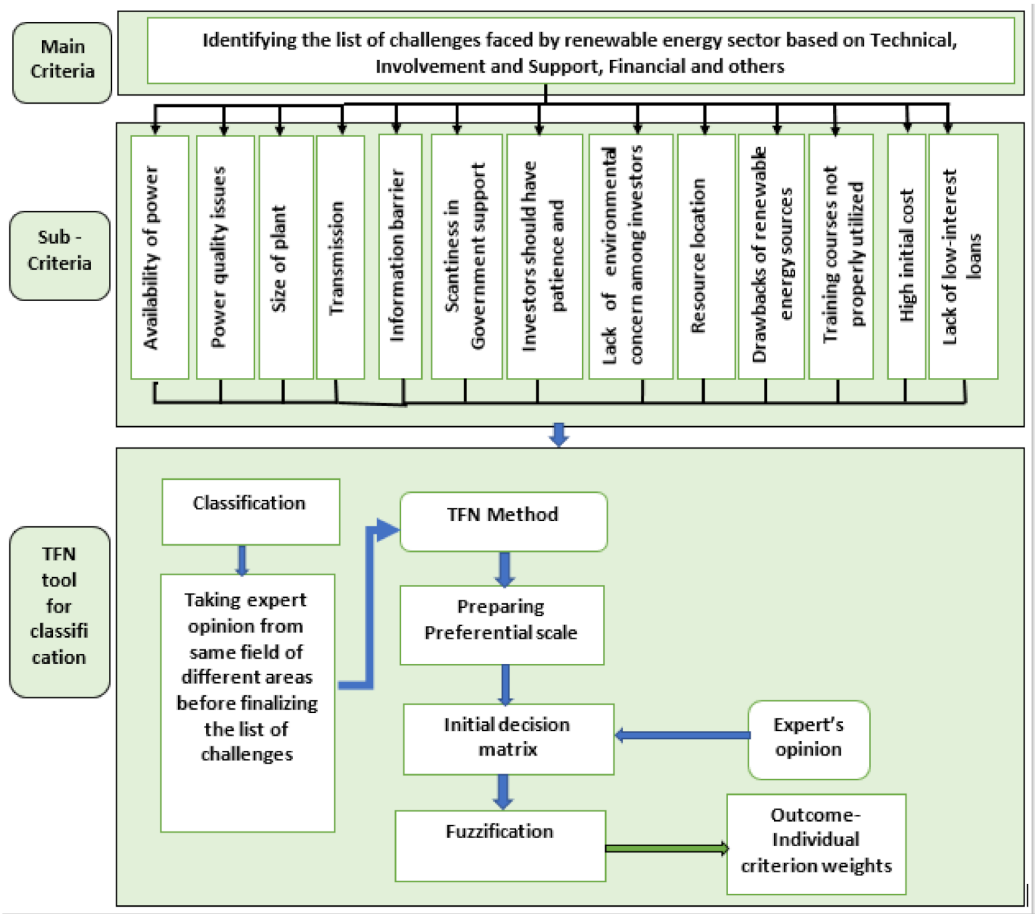

Figure 1. Workflow to identify and assess challenges in the renewable energy sector.

The challenges considered for evaluation are: availability of power (C1), power quality issues (C2), size of plant (C3), transmission (C4), information barrier (C5), scantiness in government support (C6), investors should have patience and perseverance (C7), lack of environmental concern among investors (C8), resource location (C9), drawbacks of renewable energy sources (C10), training courses not properly utilized (C11), high initial cost (C12), and lack of low-interest loans (C13), as summarized in Figure 2 under different factors. Table 1 shows the selected factors with their literature references.

The traditional renewable energy sources, especially wind, solar and hydro energy, have long been used by man to generate electricity. Since many decades, even biomass energy has been in existence in a much raw form. On the other hand, sources like tidal and geothermal energy seems also promising as the latest for promoting a developing nation like India. As of the most benefitted energy system hydro energy, it is quite a popular energy resource within the nation. The supply of abundant amount of water and river resources as well as moderate costs of establishment and electricity generation further add up to its popularity and resourceful usage. As of geothermal energy, that as well is a largely unexplored genre of energy generation and further research is needed. Wind energy has also gained large popularity within the nation, especially within the Southern parts of India with continuous coastal supply of optimum wind to generate a continuous amount of electricity. For an agriculture-oriented country like India, biomass energy can also prove a good adoption, with enough scope and potential for generation of biomass in the form 
of agricultural wastes. With enormous potential, nuclear energy, despite low generation costs comes with many consequences. Apart from environmental hazard, establishment cost itself for a nuclear power plant is tremendously high.

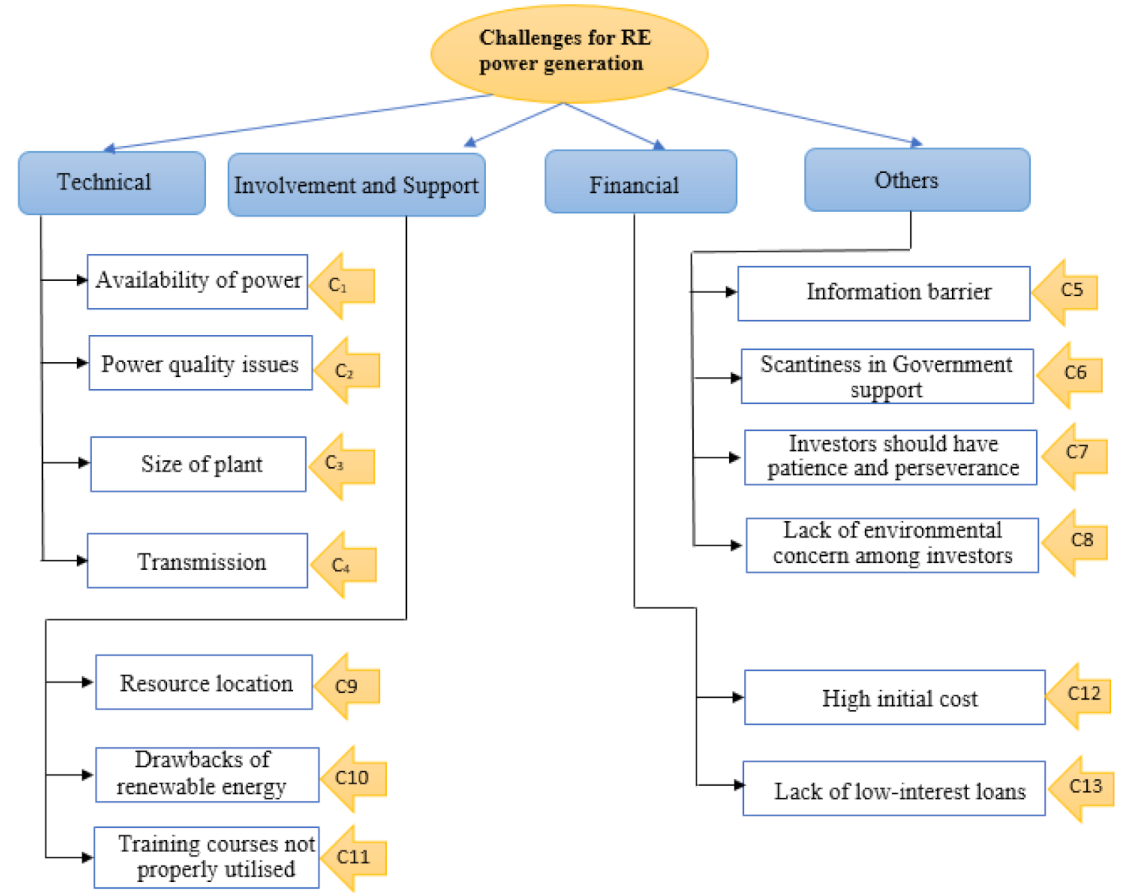

Figure 2. List of criteria considered for the case study.

The following subsections present detailed definitions, metrics, and the acquired data for each criterion used in the model.

\subsection{Challenges for RE Power Generation in India}

- Availability of power (C1):

An important concern in RE is the dependency on natural resources over which humans do not have control and which are intermittent. For instance, solar energy depends on the amount of sunshine, and it is not available at night. Wind energy depends on the amount of wind. Wind turbines do not rotate without enough wind, so there are periods of zero power supply to the grid. On the other hand, too much wind flow is not suitable for the generator, and a moderate amount is needed for continuous generation of electricity. Due to the uncertainty in energy production associated with the RE, integration with the grid is complex.

- Power quality issues (C2):

A constant supply of high-quality power is needed for efficiency and stability of the network. When the power supply quality is good, the system works properly with high reliability and low costs. A low quality of power may have major adverse effects on the industrial processes and on the power grid. This may cause additional costs and equipment failure. A poor power quality is associated with current/voltage harmonics, disorder in frequency, less power factor, variations in voltage and transmission line transits.

- $\quad$ Size of plant (C3):

Determining an optimal size of plant has been a big challenge for RE firms. Because, due to constraints in storing electricity on a large scale, energy produced more than demand requirement goes unutilized. Therefore, the plant should not be too large. On the other hand, too small of a plant may not justify the investment and the demand. 


\section{- Transmission (C4):}

For good utilization of RE sources, proper transmission infrastructure is required. Present power transmission infrastructure was mostly built during the twentieth century, and it was suited to nuclear plants and large fossil fuel plants. This often means that infrastructure objects and lines are not located near renewable energy sources and generation sites.

\section{- Information barrier (C5):}

The challenge of information barrier is reflected in the following. The awareness of $\mathrm{RE}$ is constantly growing, but the society is still largely not informed about the benefits of RE and the need for it. In establishing a RE plant in India, both capital allowances and investment support by the government are available. However, many of the potential applicants are not aware of the incentives available, or they need assistance in applying for the incentives.

\section{- $\quad$ Scantiness in Government support (C6):}

The Indian government's target of installing 175 GW of clean energy capacity by 2022 is not likely to be met. The impediments in achieving this target are related to land acquisition, tariff caps and an import duty on solar cells and other modules. The government should support the research and development of the technologies, including those in renewable energy storage. If the problem of energy storage gets overcome, the RE sector would grow, and this could reduce the dependence on the conventional energy sources.

- Investors should have patience and perseverance (C7):

The Indian RE industry has been maturing. It is growing, the perceived risks are diminishing, and the expected yields are medium to high. RE is becoming more attractive than the other infrastructure sub-sectors, particularly the fossil fuel power generation. It is currently considered as risk free in terms of returns on investment.

- $\quad$ Lack of environmental concern among investors (C8):

In principle, investors are concerned with financial benefits and some investors are interested only in quick returns. Some investors have a certain degree of concern for the environment as well. This situation could improve to some extent by educating the investors more about the RE, but more significantly, with financial incentives and regularity action and enforcement by the government.

- $\quad$ Resource location (C9):

A geographic location of a RE source has multiple effects. In most cases, RE plants need to be in specific locations, governed by the availability of the resource, such as sunlight, wind, or water flow, as well as the suitability of the terrain and other location factors. The distance between the RE sources and the grid increases the cost and decreases the efficiency of the system. A grid that includes RE plants generally requires a larger area then a grid including conventional sources only.

- Drawbacks of renewable energy sources (C10):

RE has some drawbacks. When it comes to hydro-energy, establishing hydro-electric plants can cause extinction of living organisms. Reduction in sedimentation deposition causes a decrease in land fertility, raises the risk of dam structure failure and disturbs a normal river flow, which affects the water plants and animals and increases the risk of flood. Local people may lose their homes along with source of income. Greenhouse gases emission may rise due to decomposition of immersed biomass. When it comes to wind farms, the movement of mechanical parts of the turbine may result in vibrations due to wind disturbance, and potential change in wind speed. The wind blades are a threat to flying creatures and can cause the loss of habitat. The burning of biomass may lead to loss in biodiversity. If crops are used as biomass this may reduce the amount available for produce. In the case of biomass waste, the burning of biomass waste for power generation 
may reduce the amount available for other biomass waste uses. The establishment of solar power plants may cause ecosystem imbalance. Toxic heavy metals and rare earth minerals are required to produce photovoltaic cells. Some locations experience high variations in solar radiation throughout the year, resulting in uneven power production throughout the year. The use of geothermal energy can cause water and air pollution; and it can induce micro-seismicity and land subsidence.

- Training courses not properly utilized (C11):

Training courses to educate workers about green and sustainable practices are not well developed, and the courses that exist are not used by the management.

- $\quad$ High initial cost (C12):

One of the greatest obstacles for the adoption of renewable energy is cost. The cost of building RE power generation plants is quite high. On the other hand, their operation costs are low, as the sources are free, and maintenance is low. Hence, the main cost associated with the RE projects is their initial cost. Because of this, the lenders perceive these projects as high-risk, which affects the borrowing rates, and this in turn makes it more difficult to justify an investment. The cost also refers to the costs associated with R\&D investments.

- $\quad$ Lack of low-interest loans (C13):

Lack of low-interest loans. Banks are risk-averse, and since the environmentally friendly and sustainable industry has not yet proven to be highly profitable, the availability of bank loans for sustainable projects is limited, and their interest rates are high. The challenges identified were grouped in the following categories: Technical, Involvement and Support, Financial and Others, as shown in Table 1.

\subsection{Ranking of the Challenges Using Triangular Fuzzy Number (TFN)}

Fuzzy set theory (FST) was proposed in 1965 [43] to deal with uncertainty of a solution where input information is not complete [44]. A degree of judgment is involved in decisionmaking, represented with a set of three numbers [44,45].

In a generalized fashion, a triangular fuzzy number (TFN) is represented as shown in Equation (1), where d1 indicates minimum boundary limit for the judgment's uncertainty, $d 2$ represents its median value, and $d 3$ represents its maximum limit [44]. The TFN technique is extremely useful in situations where information has some level of subjectivity $[44,46]$.

The function of fuzzy membership can be given as:

$$
\mu\left(\frac{A}{B}\right)=\left\{\begin{array}{cc}
0 & ; A \leq d_{1} \\
\frac{\left(A-d_{1}\right)}{\left(d_{2}-d_{1}\right)} ; & d_{1} \leq A \leq d_{2} \\
\frac{\left(d_{3}-A\right)}{\left(d_{3}-d_{2}\right)} ; & d_{2} \leq A \leq d_{3} \\
0 & ; A \geq d_{3}
\end{array}\right\}
$$

where ' $A$ ' represents a real number.

The operations of addition and division of any two TFNs, $B_{1}=\left(r_{1}, s_{1}, t_{1}\right)$ and $B_{2}=\left(r_{2}, s_{2}, t_{2}\right)$, are as follows:

$$
\begin{gathered}
B_{1}+B_{2}=\left(r_{1}+r_{2}, s_{1}+s_{2}, t_{1}+t_{2}\right) \\
B_{1} / B_{2}=\left(r_{1} / r_{2}, s_{1} / s_{2}, t_{1} / t_{2}\right)
\end{gathered}
$$

The scale of preference using the TFN method to compare two items is shown in Table $2[47,48]$. 
Table 1. Challenges for RE power generation.

\begin{tabular}{|c|c|c|c|c|}
\hline NO. & Factor & Challenges & Symbol & Reference \\
\hline \multirow[t]{4}{*}{1.} & Technical & Availability of power & $\mathrm{C} 1$ & {$[49,50]$} \\
\hline & & Power quality issues & $\mathrm{C} 2$ & {$[51,52]$} \\
\hline & & Size of plant & $\mathrm{C} 3$ & {$[53,54]$} \\
\hline & & Transmission & $\mathrm{C} 4$ & {$[55,56]$} \\
\hline \multirow[t]{4}{*}{2.} & Others & Information barrier & C5 & {$[49,50]$} \\
\hline & & Scantiness in Government support & C6 & {$[55,57]$} \\
\hline & & Investors should have patience and perseverance & $\mathrm{C} 7$ & {$[58,59]$} \\
\hline & & Lack of environmental concern among investors & $\mathrm{C} 8$ & {$[60,61]$} \\
\hline \multirow[t]{3}{*}{3.} & $\begin{array}{c}\text { Involvement and } \\
\text { Support }\end{array}$ & Resource location & C9 & {$[62,63]$} \\
\hline & & Drawbacks of renewable energy sources & C10 & {$[53,58]$} \\
\hline & & Training courses not properly utilized & C11 & {$[55,58]$} \\
\hline \multirow[t]{2}{*}{4.} & Financial & High initial cost & $\mathrm{C} 12$ & {$[50,63]$} \\
\hline & & Lack of low-interest loans & $\mathrm{C} 13$ & {$[58,59]$} \\
\hline
\end{tabular}

Table 2. Preferential Scale for TFN method to rank challenges [47].

\begin{tabular}{cccc}
\hline No. & Linguistic Scale & Associated TFN & Reciprocal TFN \\
\hline 1 & Equally Favored & $(1,1,1)$ & $(1,1,1)$ \\
2 & Weakly to Moderately Favored & $(1,2,3)$ & $(1 / 3,1 / 2,1)$ \\
3 & Moderately Favored & $(2,3,4)$ & $(1 / 4,1 / 3,1 / 2)$ \\
4 & Moderately to Strongly Favored & $(3,4,5)$ & $(1 / 5,1 / 4,1 / 3)$ \\
5 & Strongly Favored & $(4,5,6)$ & $(1 / 6,1 / 5,1 / 4)$ \\
6 & Strongly to Very Strongly Favored & $(5,6,7)$ & $(1 / 7,1 / 6,1 / 5)$ \\
7 & Very Strongly Favored & $(6,7,8)$ & $(1 / 8,1 / 7,1 / 6)$ \\
8 & Very Strongly to Extremely Favored & $(7,8,9)$ & $(1 / 9,1 / 8,1 / 7)$ \\
9 & Extremely Favored & $(8,9,9)$ & $(1 / 9,1 / 9,1 / 8)$ \\
\hline
\end{tabular}

The total integral value method, using fuzzy numbers [48], is chosen for ranking of the challenges. The steps involve the calculations with TFNs $B_{i j}=\left(r_{i j}, s_{i j}, t_{i j}\right)$, and they are as follows:

Step 1: A decision matrix for pairwise comparisons of all the considered criteria (in this case, the 13 challenges) is made, applying the comparison scheme from Table 2 . The authors prepared a questionnaire corresponding to the decision matrix and using the TFN method nine-point linguistic scale. The comparisons represent the opinions of experts from related fields of study, along with circumstantial preference of decision maker. The responses of the three experts are shown in decision matrices, in Tables A1 to A3 in the Appendix A. Inputting these values into Equations (4)-(11), described below, the weight of each challenge was found.

Step 2: A synthetic extent value is given as:

$$
\begin{gathered}
G_{i}=\sum_{j=1}^{n} B_{i j} \times \frac{1}{\left[\sum_{i=1}^{m} \sum_{j=1}^{n} T_{i j}\right]} \\
\frac{1}{\left[\sum_{i=1}^{m} \sum_{j=1}^{n} B_{i j}\right]}=\left(\frac{1}{\sum_{i=1}^{m} \sum_{j=1}^{n} t_{i j}}, \frac{1}{\sum_{i=1}^{m} \sum_{j=1}^{n} s_{i j}}, \frac{1}{\sum_{i=1}^{m} \sum_{j=1}^{n} r_{i j}}\right)
\end{gathered}
$$


Further, it was found that the previous research in this area proposed a few alterations and simplifications to the Equation (5) for the synthetic extent value. Implementing these modifications gives a re-arranged equation [43]:

$$
\frac{1}{\sum_{i=1}^{m} \sum_{j=1}^{n} B_{i j}}=\left(\begin{array}{c}
\frac{1}{\sum_{j=1}^{n} r_{i j}+\sum_{i=1}^{m} \sum_{j=1}^{n} t_{i j}}, \frac{1}{\sum_{i=1}^{m} \sum_{j=1}^{n} s_{i j}}, \\
\frac{1}{\sum_{j=1}^{n} t_{i j}+\sum_{i=1}^{m} \sum_{j=1}^{n} r_{i j}}
\end{array}\right)
$$

Step 3: After obtaining the synthetic extent value, using the comparison values and the calculations above, the degree of possibility of each respective criterion is obtained as follows:

$$
\begin{gathered}
V\left(G_{j} \geq G_{i}\right)=\text { Height }\left(G_{i} \cap G_{j}\right) \\
=1, \text { if } s_{j} \geq s_{i} \\
=0, \text { if } r_{i} \geq t_{j} \\
=\frac{r_{i}-t_{j}}{\left(s_{j}-t_{j}\right)-\left(s_{i}-r_{i}\right)} \text { otherwise }
\end{gathered}
$$

The maximum point of interaction $(Q)$ is given within the specified boundaries of $\mu G_{j}$ and $\mu G_{i}$ as shown in Figure 3. Here the membership value range is from 0 to 1 as per the standard followed for assigning membership value in fuzzy logic.

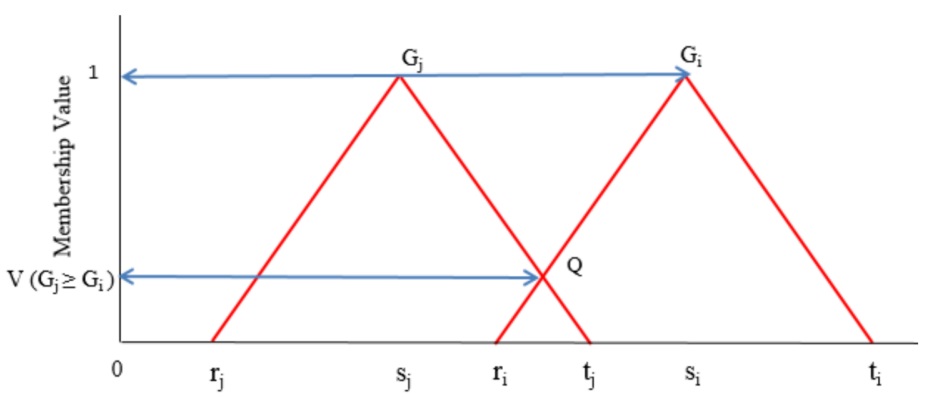

Figure 3. Highest interaction points between $G_{j}$ and $G_{i}$.

Step 4: Making the following assumptions:

$$
s *\left(H_{i}\right)=\min B\left(G \geq G_{i}\right) ; \quad(i=1,2,3, \ldots k)
$$

The weight vector $C^{*}$ can be obtained as:

$$
c *=\left(s *\left(H_{1}\right), s *\left(H_{2}\right) \ldots, s *\left(H_{n}\right)\right)^{T}
$$

Step 5: The Equation (10) shown below is usually used to find normalized weight vectors for the challenges. However, later modifications of the total integral value system [43], by applying the methodology described, result in Equation (11), as shown below:

$$
\begin{aligned}
C & =\left(s\left(H_{1}\right), s\left(H_{2}\right) \ldots, s\left(H_{n}\right)\right)^{T} \\
I_{T}^{\beta}\left(G_{j}\right) & =\frac{1}{2} \beta\left(s_{j}+t_{j}\right)+\frac{1}{2}(1-\beta)\left(r_{j}+s_{j}\right) \\
& =\frac{1}{2}\left[\beta t_{j}+s_{j}+(1-\beta) r_{j}\right]
\end{aligned}
$$

where $\beta$ value has a range between 0 and 1 , and it represents the degree of optimism from the perspective of the decision-maker. The value adopted for $\beta$ in this study is 0.5 [43].

\section{Expert Selection}

Once the methodology has been established as the TFN-based fuzzy method, and the steps for the same has been elucidated, next comes the actual calculation process. For 
this, as initially discussed in steps of the fuzzy method, first the need arises for the initial decision matrix.

To carry out an evaluation process with adequacy, mainly to obtain relative weights of the criteria, a team of experts were consulted comprising of an official from a renewable energy development agency (E1), engineers from a prominent Indian company specializing in renewable energy sector (E2) and third is a team of research scholars from a renowned foreign university (E3). Reasons for choosing these experts were logical like official from a renewable energy development agency (E1) was opted since the case study is identifying challenges and the official is one of the board members for renewable energy strategies made. Engineer from a prominent Indian company specializing in renewable energy sector (E2) was consulted to take an idea on the technical criteria chosen for the establishment. Research scholars' team (E3) is chosen as these scholars have numerous papers in suitability analysis for location of solar and wind plants. These experts were sensitized about the research area the authors are working at present. Motive and need of the work were explained to the team of experts. Based on their opinion, using Table 2 for the data values, Tables A1 to A3 were formulated as shown in Appendix A.

\section{Results and Discussions on TFN-Based Fuzzy Method}

Table 3 and Figure 4 show the final integral values of the challenges considered, with the challenges ranked by their integral values, whereas Figure 5 shows the final integral values as percentages. This helps in better understanding of the results with influence each challenge possess.

Table 3. Integral values of factors/challenges considered.

\begin{tabular}{cc}
\hline Factors/Challenges & Integral Values \\
\hline C12 & 0.131 \\
C6 & 0.123 \\
C11 13 & 0.117 \\
C9 & 0.109 \\
C5 & 0.101 \\
C1 & 0.1 \\
C3 & 0.069 \\
C7 & 0.053 \\
C10 & 0.051 \\
C4 & 0.038 \\
C 2 & 0.035 \\
C2 & 0.03 \\
\end{tabular}

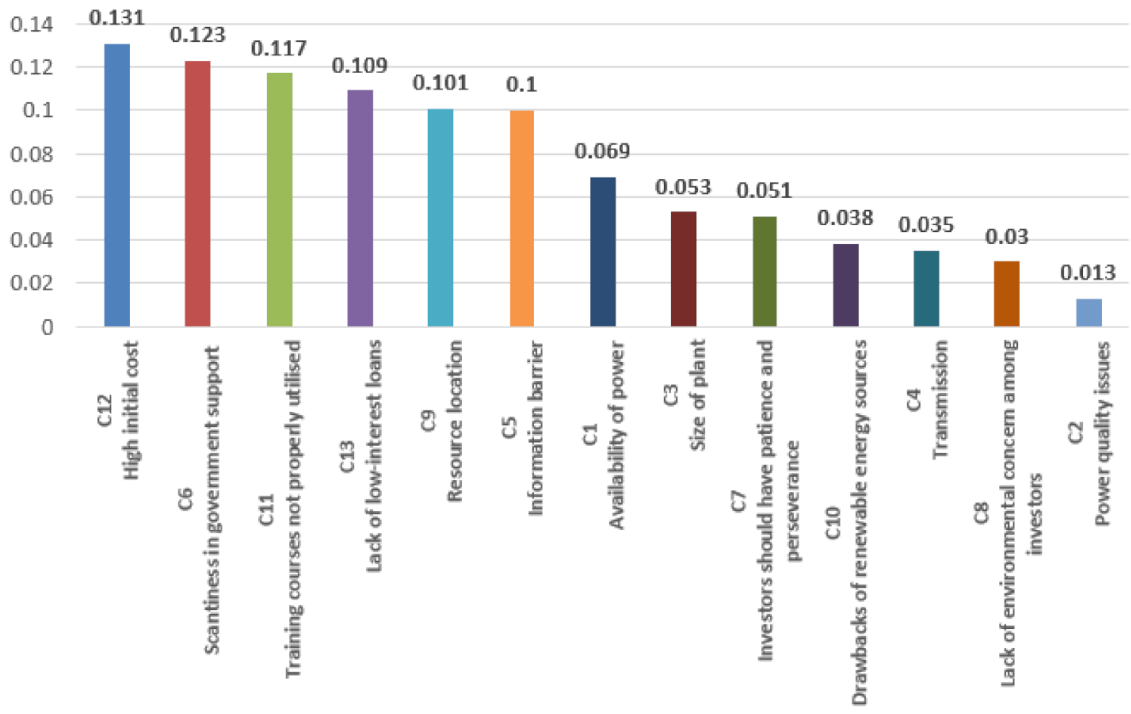

Figure 4. Ranking of the challenges by integral values. 


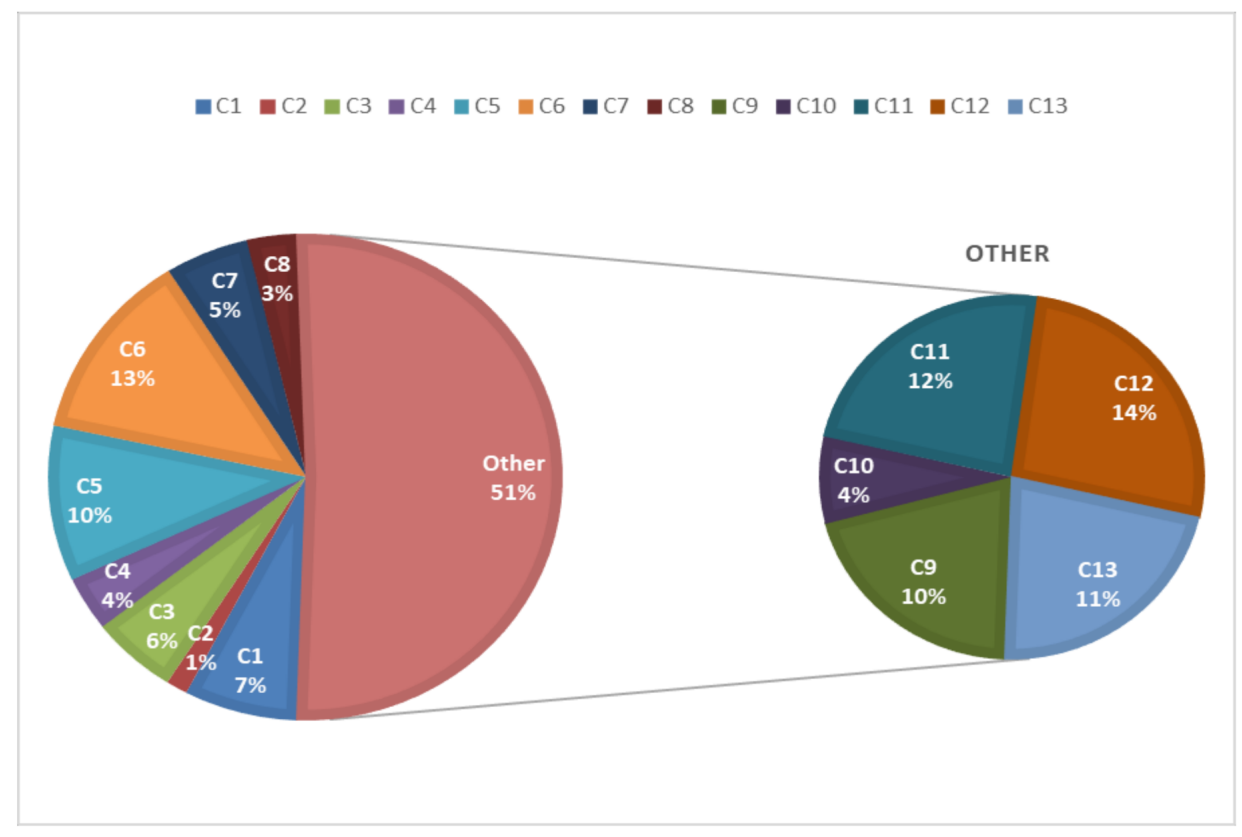

Figure 5. Figure depicting the influence of challenges in terms of percentage.

According to these results, C12-high initial cost is the greatest challenge faced by renewable energy sector. This challenge is closely followed by C6-scantiness in government support, C11 - training courses not properly utilized, C13-lack of low interest loans, C9-resource location and C5 formation barrier. These top six challenges account for $70 \%$ of the overall challenge identified, and the relative importance of these six challenges is evenly distributed. It should be noted that the government can mitigate four out of these top six challenges (all except high initial cost for resource location). It should also be noted that there is interaction between some of the challenges. For example, if low-interest loans for RE development were more widely available (C13), then the high initial cost (C12) would probably not be such a large obstacle.

\section{Conclusions}

The establishment of any non-conventional energy source for power generation and its use involves both large investment and skilled people, and this raises the importance of planning for the success of such an investment.

The main objective of this study has been to identify the major challenges in the use of RE for power generation in India and rank them in order of importance. The results of the study reveal that the greatest impediment to more significant electricity production from renewable sources is the high initial cost of RE power plants, which also refers to the costs associated with R\&D investments (C12), combined with the scantiness in government support (C6). Having the challenges identified and ranked is a step that can help planners overcome those challenges and, in turn, make the power generation industry more environmentally friendly.

As a developing country, India relies on investments by both the government and the private firms for its economic growth. Both the government and the private sector are discouraged by the high initial cost of renewable energy and the lack of surety of getting a return on the investment. Scantiness in government support (C6), training courses not properly utilized (C11) and lack of low interest loans from the banks (C13) were found to be the other most influential challenges. The analysis of all thirteen challenges reveals that it is necessary to resolve some of these challenges for the development of the renewable energy sector in the future.

When data are not concrete, but rather, include assumptions and somewhat subjective values, such as expert judgment, the use of fuzzy logic is advantageous for calculations 
with such data, as it provides a much-needed flexibility and increases the stability of the solution. In this case, the advantage of using fuzzy numbers is that it allows a mere larger relaxation in selecting and analyzing challenges associated with the renewable energy system. Additionally, for creation and calculation of the decision matrix, interval numbers in a specific choice of hierarchy of one alternative over the other was used, for decision makers this is an easier scheme of ranking. The aim of this study was to develop an adaptable and flexible approach for identifying and ranking challenges. In future research, analyzing additional data, including more challenges to carry out the study, may lead to more unambiguous and steady output on different grounds.

Moreover, future research could examine the interactions between the challenges, and the dynamics among the challenges, which could provide insightful information helpful in overcoming multiple challenges with the same set of actions. Additionally, further study of the challenges specific to different types of renewable energy and their relative importance would provide more specific information for future action.

Author Contributions: Conceptualization, S.; methodology, S. and N.K., M.A.A., H.M.; software, S.; validation, N.K.; formal analysis, S.; investigation, S., M.A.A., H.M. and N.K.; resources, S. and N.K.; data curation, S.; writing-S.; writing — review and editing, N.K. and V.K.J.; visualization, N.K. and V.K.J.; supervision, N.K. and V.K.J.; project administration, M.A.A., H.M., M.E.N.; funding acquisition, M.A.A., H.M., M.E.N. All authors have read and agreed to the published version of the manuscript.

Funding: The authors extend their appreciation to the Researchers Supporting Project at King Saud University, Riyadh, Saudi Arabia, for funding this research work through the project number RSP2021/278. The authors extend their appreciation to the Researchers Supporting Project of Intelligent Prognostic Private Limited India, for funding this research work.

Institutional Review Board Statement: Not applicable.

Informed Consent Statement: Not applicable.

Data Availability Statement: Not applicable.

Acknowledgments: Authors are thankful to Kind Saud University, Saudi Arabia, Intelligent Prognostic Private Limited Delhi India, Sikkim Manipal Institute of Technology, Manipal University Jaipur and Manipal Institute of Technology, Manipal Academy of Higher Education, Manipal for providing all necessary technical and non-technical support for the present work.

Conflicts of Interest: The authors declare no conflict of interest. 


\section{Appendix A}

Table A1. Decision Matrix by expert 1 for TFN method.

\begin{tabular}{|c|c|c|c|c|c|c|c|c|c|c|c|c|c|}
\hline & E1 & $\frac{E_{1}}{2}$ & E1 & $\mathrm{ET}$ & $E^{15}$ & $\begin{array}{ll}\text { E1 } \\
\text { C6 }\end{array}$ & E1 & $\begin{array}{ll}E 1 \\
C 8\end{array}$ & E1 & $\begin{array}{ll}\text { E1 } \\
10\end{array}$ & $\frac{E 1}{C E 1}$ & $\frac{E 1}{C 12}$ & $\frac{E 1}{C 13}$ \\
\hline $\mathrm{C} 13$ & $(1 / 4,1 / 3,1 / 2)$ & $(1 / 6,1 / 5,1 / 4)$ & $(1 / 7,1 / 6,1 / 5)$ & $(1 / 7,1 / 6,1 / 5)$ & $(5,6,7)$ & $(5,6,7)$ & $(1 / 8,1 / 7,1 / 6)$ & $\frac{18}{(1,1,1)}$ & $(1,1,1)$ & $(1 / 3,1 / 2,1)$ & $(1 / 3,1 / 2,1)$ & $(1 / 9,1 / 19,1 / 8)$ & $\frac{(1,1,1)}{(1,1)}$ \\
\hline $\begin{array}{l}\text { C12 } \\
\mathrm{C} 11\end{array}$ & $\begin{array}{r}(1 / 7,1 / 1,6,15) \\
(1 / 4,1 / 3,1 / 2)\end{array}$ & $\frac{(1 / 1,1 / 8,1 / 7)}{(1 / 9,1 / 9,1 / 8)}$ & $\frac{(1 / 8,1,17,1 / 6)}{(1 / 6,1 / 1,1 / 4)}$ & $\frac{(199,1 / 8,1 / 7)}{(1 / 5,1 / 1 / 1 / 3)}$ & $\frac{(5,6,7)}{(1 / 8,1 / 7,1 / 6)}$ & $\frac{(7,8,9)}{(6,7,8)}$ & $\frac{(1 / 1,9 / 1,9,1 / 8)}{(1 / 3,1 / 2,1)}$ & $\frac{(1 / 3,1 / 2,1)}{(1 / 7,1 / 1 / 1 / 5}$ & $\frac{(1 / 8,1 / 7,1 / 6)}{(1 / 7,16,1 / 5)}$ & $\begin{array}{l}(1 / 4,1 / 3,1 / 2) \\
(1 / 5,1 / 4,1 / 3)\end{array}$ & $\begin{array}{l}(1 / 3,1 / 2,1) \\
(1,1,1)\end{array}$ & $\begin{array}{l}(1,1,1) \\
(1,2,3)\end{array}$ & $\frac{(8,9,9)}{(1,2,3)}$ \\
\hline $\mathrm{C} 10$ & $\begin{array}{l}(1 / 3,1 / 2,1) \\
(19,9,1)\end{array}$ & $(1 / 4,1 / 3,1 / 2)$ & $\begin{array}{c}(3,4,5) \\
(1,8,17\end{array}$ & $\begin{array}{c}(1,2,3) \\
\end{array}$ & $(2,3,4)$ & $(1,2,3)$ & $\frac{(17,1,1)}{(1,1,1)}$ & $\frac{1(1 / 1,1 / 1,1 / 1 / 4)}{1}$ & $\frac{1}{(3,4,5)}$ & $\frac{(1,1,1)}{(1,1)}$ & $\frac{(1,4,5)}{(3,4,5)}$ & $\frac{(1,2,3,4)}{(2,3)}$ & $(1,2,3)$ \\
\hline $\begin{array}{l}\mathrm{C} 9 \\
\mathrm{C} 8\end{array}$ & $\frac{(1 / 9,1 / 9,1 / 8)}{(1,1,1)}$ & $\begin{array}{r}(1 / 9,1 / 9,1 / 8) \\
(1 / 3,1 / 2,1)\end{array}$ & $\frac{(1 / 8,1 / 7,1 / 6)}{(1,1,1)}$ & $\frac{(1 / 8,1 / 7,1 / 6)}{(1,1,1)}$ & $\frac{(3,4,5)}{(6,7,8)}$ & $\frac{(1,2,3)}{(2,3,4}$ & $\frac{(1,1,1)}{(1 / 3,1 / 2,1)}$ & $\begin{array}{r}(1,2,3) \\
(1,1,1)\end{array}$ & $\frac{(1,1,1)}{(1 / 3,1 / 2,1)}$ & $\frac{(1 / 5,1 / 4,1 / 3)}{(4,5,6)}$ & $\frac{(5,6,7)}{(5,6,7)}$ & $\frac{(6,7,8)}{(1,2,3)}$ & $\frac{(1,1,1)}{(1,1,1)}$ \\
\hline $\mathrm{C} 7$ & $(1 / 3,1 / 2,1)$ & $\begin{array}{c}(1,1,1) \\
\end{array}$ & $(1 / 8,1 / 7,1 / 6)$ & $(1 / 3,1 / 2,1)$ & $(1 / 4,1 / 3,1 / 2)$ & $(2,3,4)$ & (1) 11) & $\frac{1,2,3)}{(1,2,3)}$ & $\frac{(1 / 7,1 /, 1,1)}{(1,1,1)}$ & $\frac{(4,,, 0)}{(1,1,1)}$ & 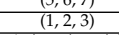 & $\frac{(1,2,9)}{(8,9,9)}$ & $\frac{(1,1,1)}{(6,7,8)}$ \\
\hline$\frac{\mathrm{C} 6}{\mathrm{C} 5}$ & $\frac{(1,1,1)}{(1 / 3,1 / 2,1)}$ & $\frac{(1 / 4,}{(1)}$ & $\begin{array}{c}(1 / 7,1 / 6,1 / 5) \\
(1 / 7,1 / 6,1 / 5)\end{array}$ & & $\frac{(1 / 5,1 / 4,1)}{(1,1,1)}$ & $\frac{(1,1,1)}{(3,4,5)}$ & $\frac{(1 / 4,4 / 1,1,1 / 2}{(2,3,4)}$ & $\frac{(1 / 4,1 / 3,1 / 2)}{(1 / 8,1 / 7,1 / 6}$ & $\frac{(1 / 3,1 / 2,1)}{(1 / 51 / 4,1 / 3)}$ & $\begin{array}{r}(1 / 3,1 / 2,1) \\
-1 / 41 / 31 / 2)\end{array}$ & $\begin{array}{l}(1 / 8,1 / 7,1 / 6) \\
(6,78)\end{array}$ & $(1 / 9,1 / 8,1 / 7$ & $(1 / 7,1 / 6,1 / 5)$ \\
\hline $\mathrm{C} 4$ & $\frac{(1,2,1 / 1,1)}{(5,6,7)}$ & $\begin{array}{r}(1,1,1) \\
(1 / 8,1 / 7,1 \\
\end{array}$ & $\frac{(1 / 1,1 / 2,1)}{(6,7,8)}$ & $\begin{array}{r}(1 / 2,1 / 2,1) \\
(1,1,1)\end{array}$ & $\frac{(1,1,1)}{(1,2,3)}$ & $\frac{(0,4,5)}{(2,3,4)}$ & $\frac{(2,, 4)}{(1,2,3)}$ & $\frac{(1,0,1), 11,}{(1,1,1)}$ & $\frac{(1 /, 1,1 / 4,1 / 1)}{(6,7,8)}$ & $\frac{(1 / 4,1 / 1,1 / 2)}{(1 / 3,1 / 2,1)}$ & $\frac{(0,1,0)}{(3,4,5)}$ & $\frac{1 / 7,1 / 6,1 / 5}{(7,8,9)}$ & $\frac{(1 /, 1 / 6,1 / 5)}{(5,6,7)}$ \\
\hline C3 & , & $(1 / 8,1 / 7,1 / 6)$ & $(1,1,1)$ & $(1 / 8,1 / 7,1 / 6$ & $(5,67)$ & 15.67 & $(6,7,8)$ & (1) 110 & $(6,7,8)$ & $(1 / 5,1 / 4,1 / 3)$ & & $(6,7,8)$ & $(5,6,7)$ \\
\hline & $(8,9,9)$ & $(1,1,1)$ & $(6,7,8)$ & $(6,7,8)$ & $(1,1,1)$ & $(2,3,4$, & $(1,1$, & $(1,2,3)$ & $(8,9,9)$ & $(2, x)$ & $(8,9,9)$ & $(7,8,9)$ & $\left(\frac{4,5,6)}{4} \quad-\quad\right.$ \\
\hline & $(1,1,1)$ & $(1 / 9,1 / 9,1 / 8)$ & $\frac{(1 / 8,1 / 7,1 / 6)}{(1)}$ & $(1 / 7,1 / 6,1 / 5)$ & $(1,2,3)$ & $(1,1,1)$ & $(1,2,3)$ & $(1,1,1)$ & $(8,9,9)$ & $(1,2,3)$ & $(2,3,4)$ & $(5,6,7)$ & $(2,3,4)$ \\
\hline
\end{tabular}

Table A2. Decision Matrix by expert 2 for TFN method.

\begin{tabular}{|c|c|c|c|c|c|c|c|c|c|c|c|c|c|}
\hline & $\frac{\mathrm{E} 2}{\mathrm{C} 1}$ & $\frac{\mathrm{E} 2}{\mathrm{C} 2}$ & $\frac{\mathrm{E} 2}{\mathrm{C} 3}$ & $\begin{array}{ll}\mathrm{E} 2 \\
\mathrm{C} 4\end{array}$ & $\begin{array}{l}\mathrm{E} 2 \\
\mathrm{C} 5 \\
\end{array}$ & $\begin{array}{ll}\mathrm{E} 2 \\
\mathrm{C} 6\end{array}$ & $\begin{array}{ll}\mathrm{E} 2 \\
\mathrm{C} 7\end{array}$ & $\frac{\mathrm{E} 2}{\mathrm{C} 8}$ & $\begin{array}{ll}\mathrm{E2} \\
\mathrm{C} 9\end{array}$ & $\begin{array}{ll}\mathrm{E} 2 \\
\mathrm{C} 10 \\
\end{array}$ & $\begin{array}{ll}\mathrm{E} 2 \\
\mathrm{C} 11\end{array}$ & $\begin{array}{ll}\mathrm{E} 2 \\
\mathrm{C} 12 \\
\end{array}$ & $\begin{array}{l}\mathrm{E} 2 \\
\mathrm{C} 13 \\
\end{array}$ \\
\hline $\mathrm{C} 13$ & $(1 / 4,1 / 3,1 / 2)$ & $(1 / 7,1 / 6,1 / 5)$ & $(1 / 8,1 / 7,1 / 6)$ & $(1 / 8,1 / 7,1 / 6)$ & $\frac{5,7}{(5,6,7)}$ & $\frac{56}{(5,6,7)}$ & $(1 / 8,1 / 7,1 / 6)$ & $(1,1,1)$ & $\frac{(1,1,1)}{(1)}$ & $\begin{array}{c}C 10 \\
(1 / 3,1 / 2,1) \\
\end{array}$ & $\frac{C 11}{(1 / 3,1 / 2,1}$ & $\begin{array}{c}C 12 \\
(1 / 9,1 / 8,1 / 7)\end{array}$ & $\frac{C 13}{(1,1,1)}$ \\
\hline $\begin{array}{l}\text { C12 } \\
\text { C11 }\end{array}$ & $\frac{(1 / 6,1 / 5,1 / 4)}{(1 / 1,1,1 / 2,1)}$ & $\begin{array}{l}(1 / 9,1 / 8,1 / 7) \\
(1 / 9,1 / 1 / 1 / 8)\end{array}$ & $\frac{(1 / 8,1 / 7,1 / 6)}{(1 / 6,1 / 5,1 / 4)}$ & $\begin{array}{l}(1 / 9,1 / 8,1 / 7) \\
(1 / 5,1 / 4,1 / 3)\end{array}$ & $\frac{(5,6,7)}{(1 / 7,1 / 6,1 / 5)}$ & $\frac{(7,8,9)}{(6,7,8)}$ & $\frac{(1 / 9,1 / 1,1,1 / 8)}{(1,1,1)}$ & $\frac{(1 / 3,1 / 2,1)}{(1 / 7,1 / 6,1 / 5)}$ & $\frac{(1 / 9,1 / 8,1 / 7)}{(1 / 7,1 / 6,1 / 5)}$ & $\frac{(1 / 4,1 / 3,1 / 2)}{(1 / 5,1 / 4,1 / 3)}$ & $\frac{(1 / 3,1 / 2,1}{(1,1,1)}$ & $\frac{(1,1,1)}{(1,2,3)}$ & $\frac{(7,8,9)}{(1,2,3)}$ \\
\hline $\mathrm{C} 10$ & $(1 / 3,1 / 2,1)$ & $(1 / 3,1 / 2,1)$ & $\frac{(3,4,5)}{(0,5)}$ & & $(2,3,4)$ & $(1,2,3)$ & $(1,1,1)$ & $(1 / 6,1 / 5,1 / 4$ & $(3,4,5)$ & $(1,1,1)$ & $(3,4,5)$ & $\frac{(2,3,4)}{(2,4)}$ & $(1,2,3)$ \\
\hline $\begin{array}{l}\text { C9 } \\
\text { C8 }\end{array}$ & $(1 / 9,1 / 9,1 / 8)$ & $(1 / 9,1 / 8,1 / 7)$ & $(1 / 9,1 / 8,1 / 7)$ & $(1 / 8,1 / 7,1 / 6)$ & $(3,4,5)$ & $(1,2,3)$ & $(1 / 3,1 / 2,1)$ & $(1,2,3)$ & $\begin{array}{c}(1,1,1) \\
\end{array}$ & $(1 / 5,1 / 4,1 / 3)$ & $(5,6,7)$ & $(7,8,9)$ & $(1,1,1)$ \\
\hline $\mathrm{C}^{\mathrm{C}} \mathrm{C}$ & $\begin{array}{c}\frac{(1,1,1)}{(1 / 3,1 / 2,1)}\end{array}$ & $\frac{(1 / 3,1 / 2,1)}{(1,1,1)}$ & $\begin{array}{c}(1,1,1) \\
\frac{(1 / 8,1 / 7,1 / 6)}{1}\end{array}$ & $\frac{(1,1,1)}{(1 / 3,1 / 2,1)}$ & $\frac{(6,7,8)}{(1 / 4,1 / 1,1 / 2)}$ & $\frac{(2,3,4)}{(2,3,4)}$ & $\begin{array}{l}(1,1,1) \\
(1,1,1)\end{array}$ & $\begin{array}{l}(1,1,1) \\
(1,1,1)\end{array}$ & $\begin{array}{c}(1 / 3,1 / 2,1) \\
(1,2,3)\end{array}$ & $\begin{array}{l}(4,5,6) \\
(1,1,1)\end{array}$ & $\frac{(5,6,7)}{(1,1)}$ & $\frac{(1,2,3)}{(8,9)}$ & $\frac{(1,1,1)}{(6,8)}$ \\
\hline $\mathrm{C} 6$ & $\begin{array}{c}(1 /, 1,1,1) \\
(1,1)\end{array}$ & $(1 / 4,1 / 3,1 / 2)$ & $\frac{(1 / 7,1 / 1 / 6,1 / 5)}{(1 / 7,1)}$ & $(1 / 5,1 / 4,1 / 3)$ & $(1 / 5,1 / 4,1 / 3)$ & $\begin{array}{l}\frac{(1,2,4)}{(1,1,1)} \\
\end{array}$ & $\frac{(1,1,1)}{(1 / 4,1 / 3,1 / 2)}$ & $\begin{array}{c}(1,1,1) \\
(1 / 4,1 / 3,1 / 2\end{array}$ & $(11 / 3$, & $\frac{(1,1,1)}{(1 / 3,1 / 2,1)}$ & $\frac{(1,1,1)}{(1 / 8,1 / 7,1 /}$ & $\begin{array}{c}(1 / 9,1 / 8,1 / 7) \\
\end{array}$ & $(1,7,1,1 / 6,1]$ \\
\hline $\begin{array}{l}\text { C5 } \\
\text { C4 }\end{array}$ & $(1 / 4,1 / 3,1 / 2)$ & $\begin{array}{c}(1,1,1) \\
\end{array}$ & $(1 / 8,1 / 7,1 / 6)$ & $(1 / 3,1 / 2,1)$ & $(1,1,1)$ & $(3,4,5)$ & $(2,3,4)$ & $(1 / 8,1 / 7,1 / 6)$ & $(1 / 5,1 / 4,1 / 3)$ & $(1 / 4,1 / 3,1 / 2)$ & $\frac{(5,6,7)}{(5,7)}$ & $(1 / 7,1 / 6,1 / 5)$ & $(1 / 7,1 / 6,1 / 5$ \\
\hline $\mathrm{C}^{\mathrm{C}} \mathrm{C}$ & $\begin{array}{l}(5,6,7) \\
(5,6,7)\end{array}$ & $\begin{array}{r}-(1 / 9,1 / 8,1 / 7) \\
(1 / 8,1 / 7,1 / 6)\end{array}$ & $\frac{(5,6,7)}{(1,1)}$ & $\frac{(1,1,1)}{(1 / 7,1 / 6,1 / 5)}$ & $\frac{(1,2,3)}{(6,7,8)}$ & $\frac{(3,4,5)}{(5,6,7)}$ & $\frac{(1,2,3)}{(6,7,8)}$ & $\frac{(1,1,1)}{(1,11)}$ & $\frac{(6,7,8)}{(8,8,9)}$ & $\begin{array}{r}(1 / 3,1 / 2,1) \\
(1 / 5,1 / 4,1 / 3\end{array}$ & $\frac{(3,4,5)}{4,5,0}$ & $\begin{array}{l}(7,8,9) \\
(6,8)\end{array}$ & $\frac{(6,7,8)}{(6,78)}$ \\
\hline $\mathrm{C} 2_{2}$ & $(7,8,9)$ & $\frac{(1 / 7,1,1,1 / 0)}{(1,1,1)}$ & $\frac{(1,1,1)}{(6,7,8)}$ & $(7,8,9)$ & $\frac{(0,1,1)}{(1,1,1)}$ & $\frac{(2,0,1)}{(2,3,4)}$ & $\frac{(0,1,1,1)}{(1,1,1)}$ & $\frac{(1,1,1)}{(1,2,3)}$ & $\frac{(, 0,0,1)}{(7,8,9)}$ & $\frac{(1 / 2,1)}{(1,2,3)}$ & $\frac{(4,5,9)}{(8,9,9)}$ & $\frac{(0,1,0)}{(7,8,9)}$ & $\frac{(0,1,6,0)}{(5,6,7)}$ \\
\hline $\mathrm{Cl}$ & $(1,1,1)$ & $(1 / 9,1 / 8,1 / 7)$ & $(1 / 7,1 / 6,1 / 5)$ & $(1 / 7,1 / 6,1 / 5)$ & $(2,3,4)$ & $(1,1,1)$ & $\frac{1,2,3)}{(1,2)}$ & $(1,1,1)$ & $(8,9,9)$ & $(1,2,3)$ & $(1,2,3)$ & $(4,5,6)$ & $(2,3,4)$ \\
\hline
\end{tabular}

Table A3. Decision Matrix by expert 3 for TFN method.

\begin{tabular}{|c|c|c|c|c|c|c|c|c|c|c|c|c|c|}
\hline & E3 & $\mathrm{E} 3$ & E3 & E3 & E3 & E3 & E3 & E3 & E3 & $\mathrm{E} 3$ & $\mathrm{E} 3$ & E3 & E3 \\
\hline $\mathrm{C} 13$ & $(1 / 5,1 / 4,1 / 3)$ & $\frac{(2}{(1 / 6,1 / 5,1 / 4)}$ & $(1 / 8,1 / 7,1 / 6)$ & $(1 / 7,1 / 6,1 / 5)$ & $\frac{5}{(5,6,7)}$ & $\frac{C 6}{(5,6,7)}$ & $(1 / 8,1 / 7,1 / 6)$ & & & $\frac{10}{(1 / 3,1 / 2,1)}$ & & $\frac{(12}{(19,1 / 8,1 / 7)}$ & $\frac{C 13}{(1,1,1)}$ \\
\hline $\begin{array}{l}\mathrm{C} 12 \\
\mathrm{C} 11\end{array}$ & $\frac{(1 / 8,1 / 7,1 / 6)}{(1 / 5,1 / 4,1 / 3)}$ & $\begin{array}{l}(1 / 9,1 / 8,1 / 7) \\
(1 / 9,1 / 9,1 / 8)\end{array}$ & $\begin{array}{l}(1 / 8,1 / 7,1 / 6) \\
(1 / 6,15,1 / 4)\end{array}$ & $\begin{array}{l}(1 / 9,1 / 8,1 / 7) \\
(1 / 5,1 / 4,1 / 3\end{array}$ & $\frac{(5,6,7)}{(1 / 1,17.16)}$ & $\begin{array}{ll}(7,8,9) \\
6(6,78\end{array}$ & $(1 / 9,1 / 9,1 / 8)$ & $(1 / 3,1 / 2,1)$ & $(1 / 8,1 / 7,1 / 6)$ & $(1 / 3,1 / 2,1)$ & $(1 / 4,1 / 3,1 / 2)$ & $\frac{1,1,1)}{(2,4)}$ & $\frac{(7,8,9)}{(1,2)}$ \\
\hline & $\frac{(1 / 5,1 / 4,1,3)}{(1 / 3,1 / 2,1)}$ & $\begin{array}{r}(1 / 9,1 / 9,11 / 8) \\
(1 / 4,1 / 3,1 / 2)\end{array}$ & $\frac{(1 / 6,1 / 5,1 / 4)}{(3,4,5)}$ & $\frac{(1 / 5,1,4,1 / 3)}{(1,2,3)}$ & $\frac{(1 / 8,1,7,1 / 6)}{(2,3,4)}$ & $\frac{(6,7,8}{(2,3,4)}$ & $\frac{(1,1,1)}{(1,1,1)}$ & $\frac{(1 / 7,1 / 6,1 / 5)}{(1 / 6,1 / 5,1 / 4)}$ & $\frac{(1 / 7,1 / 6,1 / 5)}{(3,4,5)}$ & $\frac{(1 / 5,1 / 4,1,3)}{(1,1,1)}$ & $\frac{(1,1,1)}{(3,4,5)}$ & $\frac{(2,3,4)}{(1,2,3)}$ & $\frac{(1,2,3)}{(1,2,3)}$ \\
\hline & $(1 / 9,1 / 9,1 / 8)$ & $(1 / 9,1 / 9,1 / 8)$ & $(1 / 9,1 / 8,1 / 7)$ & $(1 / 8,1 / 7,1 / 6)$ & $(3,4$ & $\frac{(2,3,4)}{2,4}$ & पिताम & & $(1,1,1)$ & $(1 / 5,1 / 4,1 / 3)$ & $\frac{(5,6,7)}{(5,7)}$ & $\frac{(6,7,8)}{(1,2)}$ & $(1,1,1)$ \\
\hline $\begin{array}{l}\mathrm{C} 8 \\
\mathrm{C} 7\end{array}$ & $\frac{(1,1,1)}{(1,3,1 / 2,1)}$ & $\begin{array}{c}(1 / 3,1 / 2,1) \\
(11.11)\end{array}$ & $\begin{array}{c}(1,1,1) \\
(1 / 8,17,1 / 6)\end{array}$ & $\begin{array}{c}(1,1,1) \\
(113,12,1)\end{array}$ & $\begin{array}{c}(6,7,8) \\
(114,1 / 3,1 / 2)\end{array}$ & $\frac{(2,3,4)}{2,3,4}$ & $\frac{(1,1,1)}{(1,1)}$ & $\frac{(1,1,1)}{(1,1)}$ & $(1 / 3,1 / 2,1)$ & $(4,5,6)$ & $(5,6,7)$ & $\frac{(1,2,3)}{1899}$ & $\frac{1,1)}{788}$ \\
\hline & $\frac{(1 / 3,1 / 2,1)}{(1,1,1)}$ & $\begin{array}{c}(1,1,1) \\
(1 / 4,1 / 3,1 / 2)\end{array}$ & $\frac{(1 / 8,1 / 1,1 / 6)}{(1 / 7,1 / 6,1 / 5)}$ & $\frac{(1 / 3,1 / 2,1)}{(1 / 4,1 / 3,1 / 2)}$ & $\begin{array}{r}(1 / 4,1 / 7,1 / 2) \\
(1 / 5,1 / 4,1 / 3)\end{array}$ & $\frac{(2,3,4)}{(1,1,1)}$ & $\frac{(1,1,1)}{(1 / 4,1 / 3,1 / 2)}$ & $\frac{(1,1,1)}{(1 / 4,1 / 3,1 / 2)}$ & $\frac{(1,1,1)}{(1 / 4,1 / 3,1 / 2)}$ & $\frac{(1,1,1)}{(1 / 4,1 / 3,1 / 2)}$ & $\frac{(1,1,1)}{(1 / 8,1 / 7,1 / 6)}$ & $\frac{(8,9,9)}{(1 / 9,1 / 8,1 / 7)}$ & $\frac{(6,1,8)}{(7,1 / 6,1 / 5)}$ \\
\hline$C 5$ & $(1 / 3,1 / 2,1)$ & $(1,1,1)$ & $(1 / 8,1 / 7,1 / 6)$ & $(1 / 3,1 / 2,1)$ & $\frac{(1,1,1)}{(1)}$ & $3,3,4,5$ & $\frac{1,3,4)}{(2,3)}$ & $(1 / 8,1 / 7,1 / 6)$ & $(1 / 5,1 / 4,1 / 3)$ & $(1 / 4,1 / 3,1 / 2)$ & $\frac{1}{(6,7,8)}$ & $(1 / 7,1 / 6,1 / 5)$ & $77,1 / 6,1 / 5)$ \\
\hline $\mathrm{C}_{\mathrm{C}}$ & $(6,7,8)$ & $(1 / 8,1 / 7,1 / 6)$ & $(5,6,7)$ & $\begin{array}{l}(1,1,1) \\
(1 / 81 / 7016\end{array}$ & $\begin{array}{l}(1,2,3) \\
(6,8)\end{array}$ & $(2,3,4)$ & $(1,2,3)$ & $\frac{(1,1,1)}{(1,1)}$ & $\begin{array}{l}(6,7,7) \\
(6,789\end{array}$ & $(1 / 5)$ & $(3,4,5)$ & $\begin{array}{l}(7,8,9) \\
(6,8)\end{array}$ & $5,6,7)$ \\
\hline $\mathrm{C} 2$ & $\frac{(6,7,8)}{(8,9,9)}$ & $\frac{(1 / 8,1 / 7,1 / 6)}{(1,1,1)}$ & $\frac{(1,1,1)}{(6,7,8)}$ & $(1 / 8,1 / 7,0 / 6)$ & $\frac{(6,7,8)}{(1,1,1)}$ & $\frac{(4,5,6)}{(2,3,4}$ & $\frac{(6,7,7)}{(1,1,1)}$ & $\frac{(1,1,1)}{(1,2,3)}$ & $\frac{(6,7,7,9)}{(1,9), 9)}$ & $\frac{(1 / 5,1 / 4,1 / 3)}{(2,3,4)}$ & $(4,5$ & $\frac{(6,7,8)}{(7,8,9)}$ & $\frac{(5,6,7)}{(4,5,6)}$ \\
\hline C1 & $(1,1,1)$ & $(1 / 9,1 / 9,1 / 8)$ & $(1 / 7,1 / 6,1 / 5)$ & $(1 / 8,1 / 7,1 / 6)$ & $(1,2,3)$ & $(1,1,1)$ & $(1,2,3)$ & $\frac{(1,1,1)}{(1,1,1)}$ & $(8,9,9)$ & $\left(\frac{2,2,3)}{(1,2,3)}\right.$ & $(3,4,5)$ & $(6,7,8)$ & $(3,4,5)$ \\
\hline
\end{tabular}




\section{References}

1. Jackson, R.B.; Canadell, J.G.; Le Quéré, C.; Andrew, R.M.; Korsbakken, J.I.; Peters, G.P.; Nakicenovic, N. Reaching peak emissions. Nat. Clim. Chang. 2015, 6, 7-10. [CrossRef]

2. REN21. Renewables 2017: Global Status Report. Renew. Energy Policy Netw. 2017. Available online: https://www.ren21.net/gsr2017/ (accessed on 31 July 2021).

3. Khan, I.; Jack, M.W.; Stephenson, J. Analysis of greenhouse gas emissions in electricity systems using time-varying carbon intensity. J. Clean. Prod. 2018, 184, 1091-1101. [CrossRef]

4. India Has Some Huge Renewable Energy Goals. But Can They Be Achieved? CNBC. 2020. Available online: https://www.cnbc. com/2020/03/03/india-has-some-huge-renewable-energy-goals-but-can-they-be-achieved.html (accessed on 1 July 2021).

5. Renewable Energy Industry in India. India Brand Equity Foundation. 2020. Available online: https://www.ibef.org/industry/ renewable-energy.aspx (accessed on 8 July 2021).

6. 3GW of Renewable Energy Installations in India Expected to Be Impacted by COVID-19. 2020. Available online: https: //www.powertechnology.com/comment/renewable-energy-installations-india-covid-19/ (accessed on 8 July 2021).

7. COVID-19 and Indian PV: Kerala Renewables Nervous of Extended Virus Impacts. 2020. Available online: https://www.pv-tech. org/news / covid-19-and-indian-pv-kerala-renewables-nervous-of-extended-virus-impacts (accessed on 1 August 2021).

8. Strantzali, E.; Aravossis, K.; Livanos, G.A. Evaluation of future sustainable electricity generation alternatives: The case of a Greek island. Renew. Sustain. Energy Rev. 2017, 76, 775-787. [CrossRef]

9. Ahmad, S.; Tahar, R.M. Selection of renewable energy sources for sustainable development of electricity generation system using analytic hierarchy process: A case of Malaysia. Renew. Energy 2014, 63, 458-466. [CrossRef]

10. Daud, A.; Wenqi, J.; Tanveer, A. Prioritization of renewable energy source for electricity generation through AHP-VIKOR integrated methodology. Renew. Energy 2022, 184, 1018-1032.

11. Kaygusuz, K. Energy for sustainable development: A case of developing countries. Renew. Sustain. Energy Rev. 2012, 16, 1116-1126. [CrossRef]

12. Asumadu-Sarkodie, S.; Owusu, P.A. Feasibility of biomass heating system in Middle East Technical University, Northern Cyprus campus. Cogent Eng. 2016, 3, 1134304. [CrossRef]

13. Edenhofer, O.; Pichs-Madruga, R.; Sokona, Y.; Seyboth, K.; Kadner, S.; Zwickel, T.; Eickemeier, P.; Hansen, G.; Schlömer, S.; von Stechow, C.; et al. (Eds.) Renewable Energy Sources and Climate Change Mitigation; Cambridge University Press: Cambridge, UK, 2011.

14. Hák, T.; Janoušková, S.; Moldan, B. Sustainable development goals: A need for relevant indicators. Ecol. Indic. 2016, 60, 565-573. [CrossRef]

15. Owusu, P.A.; Asumadu-Sarkodie, S.; Ameyo, P. A review of Ghana's water resource management and the future prospect. Cogent Eng. 2016, 3, 1164275. [CrossRef]

16. Verbruggen, A.; Fischedick, M.; Moomaw, W.; Weir, T.; Nadaï, A.; Nilsson, L.J.; Nyboer, J.; Sathaye, J. Renewable energy costs, potentials, barriers: Conceptual issues. Energy Policy 2010, 38, 850-861. [CrossRef]

17. Aydin, N.Y.; Kentel, E.; Duzgun, H.S. GIS-based site selection methodology for hybrid renewable energy systems: A case study from western Turkey. Energy Convers. Manag. 2013, 70, 90-106. [CrossRef]

18. Castillo, C.P.; Silva, F.B.; Lavalle, C. An assessment of the regional potential for solar power generation in EU-28. Energy Policy 2016, 88, 86-99. [CrossRef]

19. Li, T.; Li, A.; Guo, X. The sustainable development-oriented development and utilization of renewable energy industry-A comprehensive analysis of MCDM methods. Energy 2020, 212, 118694. [CrossRef]

20. Mayyas, A. Using quality function deployment and analytical hierarchy process for material selection of body-in-white. Mater. Des. 2011, 32, 2771-2782.

21. Govindan, K.; Shankar, K.M.; Kannan, D. Sustainable material selection for construction industry-A hybrid multi criteria decision making approach. Renew. Sustain. Energy Rev. 2016, 55, 1274-1288. [CrossRef]

22. Srihari, K.; Raval, P. Selection of an Electric Motor for an Equivalent Internal Combustion Engine by TOPSIS Method. In Advances in Power Systems and Energy Management, Lecture Notes in Electrical Engineering; Springer: Singapore, 2018 ; Volume 436.

23. Lee, H.-C.; Chang, C.-T. A Comparative analysis of MCDM methods for ranking renewable energy sources in Taiwan. Renew. Sustain. Energy Rev. 2018, 92, 883-896. [CrossRef]

24. Brewer, J.; Ames, D.P.; Solan, D.; Lee, R.; Carlisle, J. Using GIS analytics and social preference data to evaluate utility-scale solar power site suitability. Renew. Energy 2015, 81, 825-836. [CrossRef]

25. Banerjee, S.; Majumder, M. Application of AHP for Selection of Source for Micro-grid. In Proceedings of the International Conference on Energy Efficient Technologies for Sustainability, Nagercoil, India, 7-8 April 2016.

26. Saraswat, S.K.; Digalwar, A.K.; Yadav, S.S.; Kumar, G. MCDM and GIS based modelling technique for assessment of solar and wind farm locations in India. Renew. Energy 2021, 169, 865-884. [CrossRef]

27. Badang, D.A.Q.; Sarip, C.F.; Tahud, A.P. Geographic Information System (GIS) and Multicriteria Decision Making (MCDM) for Optimal Selection of Hydropower Location in Rogongon. In Proceedings of the International Conference on Humanoid, Nanotechnolgy, Information Technology, Communication and Control, Environment and Management, Iligan City, Philippines, 29 November-2 December 2018. 
28. Zhang, C.; Chen, C.; Streimikiene, D.; Balezentis, T. Intuitionistic fuzzy MULTIMOORA approach for multi-criteria assessment of the energy storage technologies. Appl. Soft Comput. J. 2019, 19, 410-423. [CrossRef]

29. Henninger, S.; Jaeger, J.; Hofmann, T. Analytical Assessment of Renewable Energy Sources and Energy Storage Concerning their Merits for the Electric Power System. Energy Procedia 2017, 135, 398-409. [CrossRef]

30. San Cristobal, J.R. Multi-criteria decision-making in the selection of a renewable energy project in Spain: The Vikor method. Renew. Energy 2011, 36, 498-502. [CrossRef]

31. Fazelpour, F.; Roohi, E.; Tajeddin, A. Towards Efficient Implementation of Solar Plants: A Priority Analysis through Multi-criteria decision approach. In Proceedings of the IEEE International Conference on Environment and Electrical Engineering and IEEE Industrial and Commercial Power Systems Europe, Milan, Italy, 6-9 June 2017.

32. Ghose, D.; Pradhan, S. Floating solar plants-Exploring a new dimension of energy generation: A case study. Energy Sources Part A Recovery Util. Environ. Eff. 2021. [CrossRef]

33. Sapkota, K.; Sherpa, K.S. Quantum Geographic Information System (Q-GIS) based study on emerging energy scenario in Hilly Terrain. Energy Sources Part A Recovery Util. Environ. Eff. 2021. [CrossRef]

34. Diemuodeke, E.O.; Addo, A.; Oko, C.O.C.; Mulugetta, Y.; Ojapah, M.M. Optimal Mapping of hybrid renewable energy systems for locations using multi-criteria decision-making algorithm. Renew. Energy 2019, 134, 461-477. [CrossRef]

35. Al Garni, H.Z.; Awasthi, A. Solar PV power plant site selection using a GIS-AHP based approach with application in Saudi Arabia. Appl. Energy 2017, 206C, 1225-1240. [CrossRef]

36. Das, A. Renewable energy source selection using analytical hierarchy process and quality function deployment: A case study. In Proceedings of the Science Technology Engineering and Management (ICONSTEM), Chennai, India, 30-31 March 2016.

37. Ghose, D.; Naskar, S. Q-GIS-MCDA Based Approach to Identify Suitable Biomass Facility Location in Sikkim (India). In Proceedings of the IEEE International Conference on Advanced Computational and Communication Paradigms, Sikkim, India, 25-28 February 2019.

38. Ghose, D.; Naskar, S.; Roy, A.K. An Open Source Software-Q-GIS Based Analysis for Solar Potential of Sikkim (India). Int. J. Open Source Soft. Process. 2019, 10, 49-68. [CrossRef]

39. Pradhan, S.; Dipanjan, G.; Bigneswar, P. Study and Analysis of Non-Conventional Energy Sources for an Eastern State of India In Proceedings of the International Conference on Mechanical, Materials and Renewable Energy, Sikkim Manipal Institute of Technology, Sikkim, India, 6-7 December 2019; Available online: https: / aip.scitation.org/doi/abs/10.1063/5.0024238 (accessed on 10 November 2021).

40. Vargas, L.G. An overview of the analytic hierarchy process and its applications. Eur. J. Oper. Res. 1990, 48, 2-8. [CrossRef]

41. Tahri, M. The evaluation of solar farm location supplying Geographic Information System and Multi-Criteria Decision-Making methods: Case study in southern Morocco. In Proceedings of the 2nd International Conference and Exhibition on Satellite \& Space Missions, Berlin, Germany, 21-23 July 2016.

42. Al Garni, H.; Kassem, A.; Awasthi, A.; Komljenovic, D.; Al-Haddad, K. A multicriteria decision making approach for evaluating renewable power generation sources in Saudi Arabia. Sustain. Energy Technol. Assess. 2016, 16, 137-150. [CrossRef]

43. Zadeh, L.A. Fuzzy sets. Inf. Control 1965, 8, 338-353. [CrossRef]

44. Dipanjan, G.; Sudeep, P. Development of Model for Assessment of Renewable Energy Sources: A Case Study on Gujarat, India. Int. J. Ambient Energy 2019, 1-10. [CrossRef]

45. Al Garni, H.Z.; Awasthi, A. A Fuzzy AHP and GIS-based Approach to Prioritize Utility-Scale Solar PV Sites in Saudi Arabia A Fuzzy AHP and GIS-based Approach to Prioritize Utility-Scale Solar PV Sites in Saudi Arabia. In Proceedings of the IEEE International Conference on Systems, Man, and Cybernetics (SMC), IEEE SMC, Banff, ON, Canada, 5-8 October 2017.

46. Garg, R.; Kumar, R.; Garg, S. MADM-based Parametric Selection and Ranking of E-Learning Websites Using Fuzzy COPRAS. IEEE Trans. Educ. 2018, 62, 11-18. [CrossRef]

47. Kahraman, C.; Ertay, T.; Büyüközkan, G. A fuzzy optimization model for QFD planning process using analytic network approach. Eur. J. Oper. Res. 2006, 171, 390-411. [CrossRef]

48. Liou, T.S.; Wang, M.J.J. Ranking Fuzzy numbers with integral value. Fuzzy Sets Syst. 1992, 50, 247-255. [CrossRef]

49. Meet, A. Moradiya. The Challenges Renewable Energy Sources Face. AZoCleantech.com. 2019. Available online: www. azocleantech.com/article.aspx?ArticleID=836 (accessed on 1 September 2021).

50. Kochtcheeva, L.V. Renewable Energy: Global Challenges. Relat. E-Int. 2016, pp. 1-9. Available online: https:/ /www.e-ir.info/ pdf/63511 (accessed on 10 November 2021).

51. The Importance of Renewable Energy. Available online: https:/ / savetheearth.coop/importance-renewable-energy (accessed on 19 May 2020).

52. Sen, S.; Ganguly, S. Opportunities, barriers and issues with renewable energy development-A discussion. Renew. Sustain. Energy Rev. 2017, 69, 1170-1181. [CrossRef]

53. Five Challenges for Renewable Energy. Available online: https://thunderbird.asu.edu/knowledge-network/5-challengesrenewable-energy (accessed on 19 May 2020).

54. Nguyen, H.T.; Safder, U.; Nguyen, X.N.; Yoo, C. Multi-objective decision-making and optimal sizing of a hybrid renewable energy system to meet the dynamic energy demands of a wastewater treatment plant. Energy 2020, 191, 116570. [CrossRef]

55. Brett Smith, B. The Challenges Renewable Energy Sources Face. Available online: https://www.azom.com/article.aspx? ArticleID=18220 (accessed on 19 May 2020). 
56. Janda, K.; Malek, J.; Recka, L. Influence of renewable energy sources on transmission networks in Central Europe. Energy Policy 2017, 108, 524-537. [CrossRef]

57. Gupta, A.R. Financing India's renewable energy vision. ORF Issue Brief 2020, 336. Available online: https://www.orfonline.org/ research/financing-indias-renewable-energy-vision-60516/ (accessed on 10 November 2021).

58. India Set to Cross 100GW Renewable Energy Capacity Mark. Available online: https://economictimes.indiatimes.com/smallbiz/productline/power-generation/india-set-to-cross-100gw-renewable-energy-capacity-mark-in-2020/articleshow / 729787 31.cms?from $=$ mdr (accessed on 19 May 2020).

59. Renewable Energy Industry in India-Investment Opportunities Invest India. Available online: https://www.investindia.gov.in/ sector/renewable-energy (accessed on 19 May 2020).

60. The Promise and Reality of Renewable Energy. Available online: https://www.downtoearth.org.in/blog/climate-change/thepromise-and-reality-of-renewable-energy-63004 (accessed on 19 May 2020).

61. Concerns over Environment a Big Priority with Investors. Available online: https://www.pionline.com/article/20190610 /PRINT /190619992/ concerns-over-environment-a-big-priority-with-investors (accessed on 19 May 2020).

62. Abaka, J.U.; Iortyer, H.A.; Ibraheem, T.B.; Salmanu, H.; Olokede, O. Prospect and Challenges of Renewable Energy Resources Exploration, Exploitation and Development in Africa. Int. J. Eng. Res. Dev. 2017, 13, 1-5.

63. Stram, B.N. Key challenges to expanding renewable energy. Energy Policy 2016, 96, 728-734. [CrossRef] 